\title{
SOME NEW RECORDS OF APHIDIDAE IN NORTH AMERICA
}

By H. F. WILsoN, Agent and Expert

\section{INTRODUCTION}

In the following pages the writer desires to redescribe a little known aphid which is remarkably divergent from other forms of the family Aphididæ and also to give data regarding two species known for many years to occur in Europe but which have not been recorded hereto from North America.

\section{A NEW APHIS GNEMY OF BANANAS \\ Pentalonia nigronervosa Coquere ${ }^{1}$}

A species of Aphidæ has been found very abundantly on banana plants in the greenhouses of the United States Department of Agriculture and was without doubt imported on banana plants from some country where this fruit is grown.

\section{Pentalonia nigronervosa Coq.}

Winged viviparous female (Fig. 1).-General color reddish brown, eyes dark red, legs as long or longer than the body, antennæ reaching beyoud the body and honey tubes; antenne, nectaries and distal ends of the femora and tibiæ dusky red; remaining parts of the legs opaque, with a slight reddish tinge.

Antennæ situated on prominent tubercles, which are strongly gibbous on the inner side; segments 1 and 6 equal in length, 3 equal in length to 4 and 5 together, and both with ten or twelve round sensoria placed in a somewhat irregular line along the inner' side of the segment; 4 somewhat longer than 5 and with six small sensoria, three of them near the middle and three toward the distal end; 7 long and slender, with two bristlelilse hairs at the base; rings hyaline; veins distinct and bordered by dusky bands.

Veation of the wings varying considerably in individuals and often in opposite wings of the same specimen; first and second oblique veins nearly parallel, rumning transversely across the wing; cubital rein two-forked and distorted at or near the second fork, where the stigmal rein joins it, the two forming a single vein for a short distance, then separating and forming a distinct stigmal and a cubital vein. The fusing of these two veins also forms a closed cubital cell, which may or may not be called a true wing cell.

Nectaries about as long as third antennal segment and reaching slightly be-

\footnotetext{
${ }^{1}$ Am. Soc. Ent, France, p. 279 (1859). Fig.
} 
yond the cauda; on live specimens semi-erect and pointing inward; general form cylidrical, slightly constricted in middle and at a point just beyond the flangelike end; cauda rery short and ending in a globular tip.

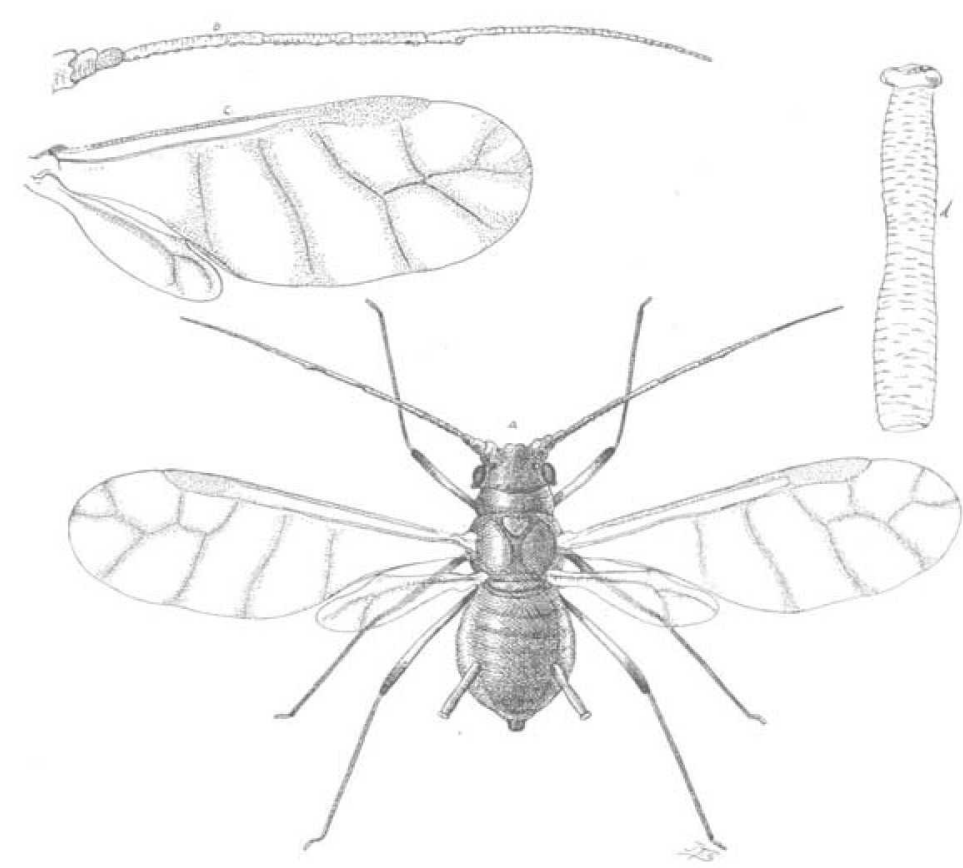

Fig. 7.-Pentalonia nigronervosa; $a$, winged viviparous female; $b$, antenna; $c$, wings; $d$, cornicles- $a$ enlarged, $b, c$ and $d$ greatly enlarged (original).

Measurements : Length of body, $1.5^{\mathrm{mm}}$; width, .75 mm; length of antenual segments (1) $.08 \mathrm{~mm},(2) .08 \mathrm{~mm},(3) .46 \mathrm{~mm},(4) .30 \mathrm{~mm}$, (5) $.20 \mathrm{~mm},(6) .09 \mathrm{~mm}$, (7) $.90^{\mathrm{mm}}$; total length, $2 \mathrm{~mm}$; length of femora on hind leg, .75 mu; tibia and tarsi, $1.25^{\mathrm{mm}}$; nectaries, $.3^{\mathrm{mm}}$; canda, $.07^{\mathrm{mm}}$.

Wingless vivipar us female (Fig. 8),-General color light reddish brown; tip of antennæ and distal ends of femorn, tibiæ and nectaries duslis; remaining parts of antennze and legs opaque, with a reddish tinge.

Antenne long, reaching back over the body past the ends of the nectaries; segments 2 and 6 equal in length, 7 as long as 3 and 4 together; antennal tubercles prominent and gibbous on the inner side; inner side of tubercles and front of head forming three sides of a rectangle; head with a slight elevation in front, on each side of which arises a short bristle. Nectaries slightly thicker than those of the winged forms but of the same length; cauda short, ending in a globular tip.

Measuremeuts : Length of body, $1.20 \mathrm{~mm}$; width, .75 min; length of antennal segments (1) $.09 \mathrm{~mm},(2) .06 \mathrm{~mm}$, (8) $.36 \mathrm{~mm}$, (4) .20 $\mathrm{mm}$, (5) $.18 \mathrm{~mm}$, (6) $.07 \mathrm{~mm}$ (7) $.60^{\mathrm{mm}}$; total length, $1.55^{\mathrm{nm}}$; nectaries, $.30^{\mathrm{mm}}$; cauda, $.06 \mathrm{~mm}$. 
Winged male (?).-The male as described is questionable. Many smallbodied individuals were found on the plants with the winged and winctess fomales. On account of the size of the abdominal cavities, which would not seem to permit the development of young, the small individuals were taken to be males.

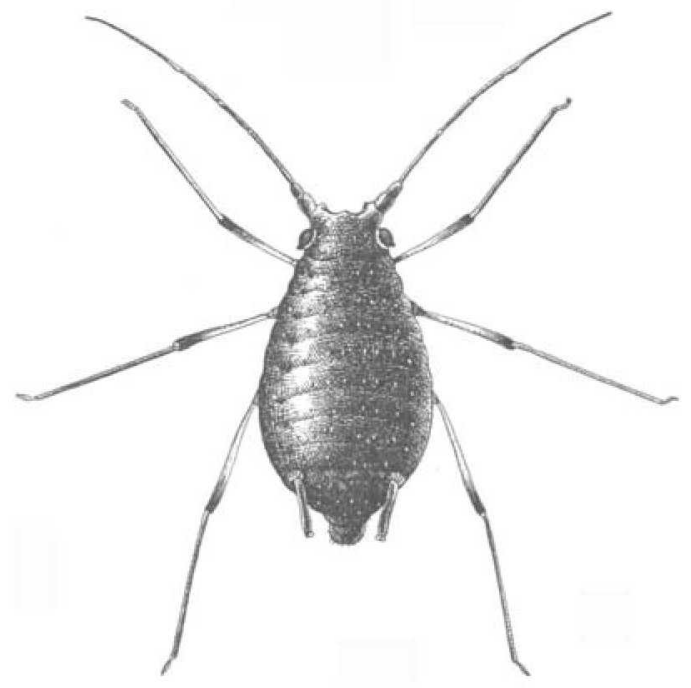

Fig. 8.-Pentalonia nigronervosa, wingless viviparous female, enlarged (original).

General coloration of parts same as in winged female, but antennæ without dusliy tips. Antennal segments 2,3 and 4 together as long as 7, which is long and slender, with a single short bristle at the tip.

The average measurements of five specimens are as follows: Length of body, $1.09 \mathrm{~mm}$; width, .45 mm; length of antenual segments, (1) .07 mm, (2).06 mm, (8) $.36 \mathrm{~mm},(4) .23 \mathrm{~mm}$, (5) .20 mm, (6) .07 min, (7) .64 mm; total length, $1.63 \mathrm{~mm}$; length of wing, $1.8 \mathrm{~mm}$; width of wing $.70 \mathrm{~mm}$.

Pupa. Similar to the wingless female and with grag wing-pads.

An ant, Prenolepis parvula Mayr, a common species about the department greenhouses, is an attendant on this aphis.

AN APBIS OCCURRING ON ANGELTCA AND IVY

Aphis angelica Koch

Specimens of Aphis angelica Koch have been received by the Bureau of Entomology on numerous occasions for determination, but there is as yet no published record of its occurrence in the United States. Koch gives as its food plant in Europe Angelica sylvestris. In California it is recorded from Angelica sp. and ivy. 
Winged viviparous female (Fig. 3).-General color grayish green, the gray being due to a pruinose secretion on the body; wings hyaline, veins clear; first 5 segments of antennæ, tip of beak, distal ends of femora and tibiæ and nectaries dusky yellow; eyes and thorax dark brown; last two segments of antenne and the abdomen green. The abdomen of some speciruens has 4 transverse, dusky dorsal bands, the edge of the fourth band coinciding with the base of the nectaries. These bands do not extend entirely across. They often merge to form an oblong black patch. An orange-colored band crosses the abdomen between the nectaries and seems to be fairly constant in all specimens.

Byes semi-prominent; beak reaching beyond the second pair of coxa; nectaries short and cylindrical; cauda obtuse, set with a few short hairs; antennæe shorter than body and very much roughened along segments 3,4 and 5 by numerous irregular sensoria; segment 3 with thirty to forty prominent sensoria, 4 with ten to fourteen, and 5 with one large sensorium always present and occasionally also one very small one; segments 1 and 2 equal in length; segment 3 longest, slightly longer than 6 and 7 together.

Measurements: Length of body, $2.30 \mathrm{~mm}$; width, .95 mm. length of wing, 3.15 $\mathrm{mm}$; total expanse, $6.9 \mathrm{~mm}$; length of antennal segments, (1) $.07 \mathrm{~mm},(2) .07 \mathrm{~mm}$, (3) $.40^{\mathrm{mm}}$, (4) $.23^{\mathrm{mm},}$, (5) $.15^{\mathrm{mm}}$, (6) .11 min, (7) $.26^{\mathrm{mm}}$; total length, $1.35 \mathrm{~mm}$; length of nectaries, .16 mm; cauda, .13 mm; width of cauda at base, $.10 \mathrm{~mm}$.

Wingless viviparous female.-General color green, covered with a fine gray pruinosity which gives them a dark appearance; eyes dark red; femora, tibix, antennæ, nectaries and cauda dusliy; remainder of body green; abdomen with a deep olange spot at the base of each nectary, and two or three transverse dusky bands crossing just behind the nectaries; antennæ and head with a few short hairs; cauda obtuse; antennre less than half as long as the body, segment 2 being the shortest and 7 the longest; nectaries cylindrical and shorter than in winged specimens.

Measurements: Length of body, $2.6^{\mathrm{mm}}$; width, $1.2 \mathrm{~mm}$; length of antennal segments, (1) $.09 \mathrm{~mm}$, (2) $.06^{\mathrm{mm}}$, (3) $.23^{\mathrm{mm}}$, (4) $.13^{\mathrm{mm}}$, (5) $.1 \mathrm{~mm}$, (6) $.09^{\mathrm{mm}}$, (7) $.27 \mathrm{~mm}$; total length, $.95^{\mathrm{mm}}$; length of nectaries, $.24 \mathrm{~mm}$; cauda, $.7 \mathrm{~mm}$; width of cenuda, .08 $\mathrm{mm}$.

Pupa.-General color green; antennæe and tibiæ dusky at distal ends; eyes black; in other respects similar to wingless females; length of body, $2 \mathrm{~mm}$; length of antennx, $.9 \mathrm{~mm}$.

\section{AN APHIS ON MAPLE IN CALIFORNIA}

\section{Drepanosiphnm platanoides Schrank}

Specimens of a large and beautiful aphis (Drepanosiphum platanoides Schranls) were sent to this bureau during the year 1908 by several correspondents on the Pacific coast. This species does not seem to have been noticed previously in North America by anyone interested in the study of aphides, and since all the specimens at hand came from California perhaps it does not occur in the more eastern states.

In the year 1848 Francis Walker ${ }^{1}$ gave an account of the life his-

${ }^{1}$ Anu. and Mag. Nat. Hist. (2), vol. 1, p. 250-254. 
tory in England and mentioned ten varieties of the species, suggesting that there is evidently quite a variation in color and size.

A very interesting difference of form is noticeable in the viviparous and oviparous females, in the shape of the body, the former being stout and short and the latter long and spindleshaped. Prof. C. P. Gillette, in describing a new species of this genus, Drepanosiphum braggii, figures the egg-laying female of that species, which shows the elongate spindleshaped abdomen, and explains the method of egg deposition.

Descriptions of the forms at hand taken on maple (Acer sp.) at Lorenzo, Cal., by Mr. I. J. Condit are given below:

Winged viviparous female-General color reddish yellow; head at base, dorsal plates of thorax, joints of legs and tarsi dark; femora and tibiæ dusky orange; antenna dusky at base, paler at tip; nectaries yellow, with dark tips ; cauda reddish yellow; wings hyaline, long, and held in horizontal position when at rest; stigma opaque; veins dusky, ending in indistinct dusky margins.

Antennæ long and slender, almost twice as long as the body, and set on large prominent tubercles; segment 3 as long as 6 and 7 together, and with fifteen to twenty or more elliptical sensoria placed in a regular line aloug the upper: outer edge of the basal half of the segment; segment 5 with one large sensorium near the distal end ; 6 with three to five large sensoria irregularly placed on the segment and distinctly separated from each other; all the segments set with short, spinelike brisles; tip of segment 7 with two setaceous hairs; bead broad, with two long and two short hairs in front; the two ocelli adjoining the eyes quite prominent and having a dusky ring around the base of each.

Prothorax long, with several tuberculate hairs on each side; abdomen robust, set with numerous short hairs arising from prominent tubercles. Legs set with numerous short bairs; tibire long and slender, femora short and stout.

Nectaries slightly curved outwardly and swollen in the middle. Cauda short and conical.

Measurements: Length of body, $2.72^{\mathrm{mm}}$; width, $1.04 \mathrm{~mm}$; length of antennal segments, (1) $.20 \mathrm{~mm}$, (2) $.08 \mathrm{~mm}$ (3) $1.6 \mathrm{~mm}$, (4) $1.2 \mathrm{~mm}$. (5) $.84 \mathrm{~mm}$, (6) $.15 \mathrm{~mm}$, (7) $1.4 \mathrm{~mm}$; total length, $5.47 \mathrm{~mm}$; length of wings, $4.8 \mathrm{~mm}$; total expanse, $10.32 \mathrm{~mm}$; length of nectaries, $.96 \mathrm{~mm}$; cauda, $.2 \mathrm{~mm}$.

Winged oviparous female.-General color reddish yellow to yellow; head, antennæ from middle of segment 3 to end of 6 , distal ends of femora and tarsi dusky; ends of nectaries dusky orange; dorsal and ventral plates of thoraz dark brown. The general characters are similar to those of the viviparous female, with the exception of the abdomen, which is longer and is spindleshaped. This form probably does not occur until fall, but as late as November the viviparous forms can be found on the underside of the leaves. Length of body, $3 \mathrm{~mm}$; other measurements as in winged, viviparous female.

Pupa.-The pupe of both forms are similar to each other, except as to the shape of the abdomen, which in the one case is robust and in the other spindleshaped. Color light reddish throughout. 